Meta

Journal des traducteurs

Translators' Journal

\title{
Aptitudes of Translators and Interpreters
}

\section{Atsuko Szuki}

Volume 33, numéro 1, mars 1988

Traduction et interprétation au Japon

Translation and Interpretation in Japan

URI : https://id.erudit.org/iderudit/004314ar

DOI : https://doi.org/10.7202/004314ar

Aller au sommaire du numéro

Éditeur(s)

Les Presses de l'Université de Montréal

ISSN

0026-0452 (imprimé)

1492-1421 (numérique)

Découvrir la revue

Citer cet article

Szuki, A. (1988). Aptitudes of Translators and Interpreters. Meta, 33(1), 108-114.

https://doi.org/10.7202/004314ar d'utilisation que vous pouvez consulter en ligne.

https://apropos.erudit.org/fr/usagers/politique-dutilisation/ 


\section{APTITUDES OF TRANSLATORS AND INTERPRETERS}

ATsuko SzUKI

Keio University

Owing to the rapid progress of technology in recent years, people have such a wide sphere of activity that the intercultural distance of time and space has been shortened. As a result, communication between people of various cultural backgrounds, that is, intercultural communication (Samovar et al. 1983), has increased and has become more complex. Differences in cultures cause inevitable misunderstanding as well as " intercultural refractions" (Uno 1981, 1984). So we need professionals engaged in occupations dealing with intercultural communication to help us avoid misunderstanding and refraction.

There are many kinds of professionals dealing with intercultural communication. Among them translators and interpreters play a very important role. According to a UNESCO survey in 1981, for example, the number of translated publications in Japanese was 2489 , the fifth highest in the world. This number comprised about one-tenth of all the publications in Japan. Translators and interpreters are essential in the fields of business, technology, science, diplomatic relations, and academic relations. Furthermore, not even a layman can go through a day without hearing translated or interpreted overseas news.

The more intercultural communication increases, the greater the need for translation and interpretation becomes. Therefore, we must prepare for this need by training as many efficient translators and interpreters as possible (Sato 1984).

As a matter of fact, the number of highly educated people, especially women, who want to become translators or interpreters has increased. Many how-to books and periodicals for translators or interpreters are published and sell well. In addition, there are 35 training schools for conference interpreters and many other training schools for translators, which are prospering (Kodaka 1984). However, despite the prosperity of these schools and publications, many future translators and interpreters have trouble discovering if they really have the aptitude for these occupations or deciding which occupation is suitable for them.

There is a pressing need for us, therefore, to know what kind of aptitude is needed to become a capable translator or a skillful interpreter.

One's aptitude, in general, is determined by several factors which are essential to accomplish a job. Ibukiyama defined aptitude as comprising mental and physiological characteristics which are required to accomplish a job (1969). D.E. Super, a vocational psychologist, defined aptitude as follows : aptitude consists of psychological factors which contribute to the success of occupations to various degrees. But he limited the meaning of aptitude to that of mental faculties such as perception and intellect (1957). Yanai divided aptitude factors into the following three parts : (1) intellectual factors, (2) personality factors and (3) physical factors. He defined aptitude as a compound of personal characteristics appropriate for a chosen career (1975). But none of these definitions mentions the concept of time. I think that within the definition of aptitude should be a factor concerning the capacity to stay in and enjoy a job, that is, to be satisfied over 
time with a particular job. Therefore, I will define aptitude as including personal characterictics which help one to choose and stick with a career.

Previous studies on vocational aptitude have been primarily concerned with intellectual factors to increase operational-efficiency or to prevent physical harm. For the most part, these studies have been done to improve management. In addition, these studies are only concerned with personality or personal interests, and not achievement motives or attitude to the job (Toyohara 1955, 1965). To compensate for this shortcoming, I will consider not only the personality and interests of subjects but also their achievement motives (Kurachi et al. 1976) and their attitudes to their jobs.

The objectives of this article are as follows :

1. To determine the statistical differences in personality and interests between translators and interpreters.

2. To show the difference between translators and interpreters in their achievement motives.

Two discriminant analyses were performed to focus on these differences. Ten personality items and ten interest items are used as independent variables, and the dependent variables are either translators or interpreters.

\section{METHOD}

Survey Design

1. Questionnaire (by mail).

2. Subjects : The total sample size of respondents was 244 people, all of whom worked for five first-rate translation/interpretration agencies in Tokyo. The final sample size was 93 (the response rate was $38 \%$ ), consisting of 30 translators, 29 interpreters and 34 "dualists". Here, dualist is used to mean a person who works as a translator and also as an interpreter.

3. Research period : from June through September 1984.

\section{Questionnaire Design} (years)

1. Demographic variables : age, sex, education, work status, work experience

2. Interest test -10 items

(1) arts (e.g. music, painting, writing,)

(2) looking after others and doing voluntary work

(3) intercultural contacts on the job (e.g. working for an international organization)

(4) knowledge of and information on international issues

(5) intercultural contacts in daily life (e.g. traveling abroad and having friends from foreign countries)

(6) clerical work

(7) physical labor

(8) journalism, mass communication and social issues

(9) verbal communication (e.g. sales)

(10) having deeper insight into people (e.g. reading psychology books)

3. Personality test -10 items
(1) patience
(2) cheerfulness
(3) activeness
(4) lie scales
(5) prudence
(6) spontaneity
(7) promptness 
(8) extroversion

(9) progressiveness

(10) empathy toward others

The results of the pilot study revealed great differences between translators and interpreters. The above items (except lie scales) were all chosen from these characteristic differences. Each item had ten questions.

4. Sentence completion test - 10 items for achievement motive, 2 items for subjects' attitude to their jobs.

Analysis Method

1. The subjects were divided into the following three groups : translators, interpreters and dualists.

2. The subjects who were well adapted to their jobs were selected from the 93 subjects (1) based on the employers' judgement regarding skillfulness, exactness of translation, frequency of requests by clients, the number of works in circulation and the employers' experience ; (2) based on two objective criteria : the subjects' experience (more than three years' experience as a full-timer or more than five years' experience as a parttimer), and their estimation of their job. For the sentence completion test, if a subject answered that he or she liked, enjoyed, or estimated highly his or her job, the subject was regarded as a well-adapted person.

The numbers of well-adapted subjects in each group are as follows :

- well-adapted translators (WAT) -21

- well-adapted interpreters (WAI) -25

- well-adapted dualists (WAD) - 19

$\begin{array}{lr}\text { 3. The scores for interest test } & 0-10 \\ \text { The scores for personality test } & 0-20 \\ \text { The scores for achievement motive } & 0-2\end{array}$

There were some subjects who did not answer all the achievement motive questions, so the scores for achievement motive were the mean of each subject's scores (achieved by dividing the sum total by the number of answers). The scores of achievement motive for each group, WAT, WAI and WAD, are shown in Table 1.

4. Two discriminant analyses, 1 and 2, were performed on items of the interest test and personality test as 20 independent variables. The differences in the characteristics of each group are shown quantitatively in Table 2, Figs. 1, 2, 3. The groups analyzed and the percentage of correct discrimination are shown in Table 2 . The values of standardized coefficient of the 20 variables by analysis 1 and analysis 2 are shown in Fig. 1, which clearly shows the differences in characteristics between WAT and WAI. The cumulative relative frequency distribution of discriminant scores of WAT and WAI by analysis 1 is shown in Fig. 2. Fig. 3 is the plotting graph of discriminant scores of each group by analysis 2 . The discriminant point of criterion 1 is 0,0 where the WAT and WAI can be distinguished. The discriminant point of criterion 2 is 0,4 , where (WAT + WAI) and WAD can be distinguished.

Discussion of Results

The significant variables, that is, the characteristics of each group, are arranged for the vocational aptitude of translators, interpreters and dualists as follows :

Aptitude of Translators

(1) Have interest in arts, especially in writing novels, screen plays, drama, baiku and poems

(2) Have interest in looking after others and voluntary work

(3) Have interest in intercultural contact on the job and in daily life 


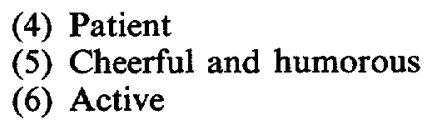

Aptitude of Interpreters

(1) Have interest in deepening insight into people

(2) Have interest in verbal communication

(3) Have interest in journalism, mass communication, and social issues

(4) Have interest in physical labor

(5) Have strong empathy toward others

(6) Progressive

(7) Extrovert

(8) Have high achievement motive

\section{Aptitude of Dualists}

(1) Have interest in looking after others and voluntary work

(2) Have interest in deepening insight into people

(3) Prompt

(4) Have very high achievement motive

With respect to the aptitude of translators, items (1) interest in arts, (3) interest in intercultural contacts, and (4) patience are essential. This result is compatible with the inferences. But item (2) interest in looking after others, (5) cheerfulness and humor and (6) activeness are limited findings. The latter three are seemingly incompatible with former. However, their consistency can be explained by the fact that jobs which require looking after others demand patience (e.g. nursing, counseling, volunteering and teaching). Thus, (2), (5), (6) are compatible with (4) patience. (5) cheerfulness and humor and (6) activeness are also understandable in relation to (2) interest in looking after others, because you need cheerfulness, humor and activeness when you look after others.

The aptitude of interpreters is compatible with the inferences. Interpreters have an interest in (1) deepening insight into people, (2) verbal communication, and (3) mass communication, journalism, social issues, and demonstrate (5) strong empathy toward others, (6) progressiveness, (7) extroversion and (8) high achievement motive. The result that interpreters (4) have interest in physical labor is understandable because, according to some veteran interpreters, interpreting involves to some extent a physical response. The content analysis of the answers for the question about what they think of their jobs shows that interpreters generally tended to enjoy, estimate highly and be satisfied with their job. This result is compatible with item (8) have very high achievement motive.

The aptitude of the dualists is the combination of the aptitude of translators and that of interpreters, that is, (1) interest in looking after others and (2) interest in deepening insight into people. The characteristics of (3) promptness and (4) very high achievement motives are convincing when you think that dualists have to manage two different types of jobs.

As mentioned above, the differences in the aptitude of translators and interpreters (and dualists) can be shown quantitatively. The following two objectives of the research were attained :

(1) To determine the statistical difference in personality and interest between translators and interpreters. 
(2) To show the differences between translators and interpreters in the achievement motives.

By studying further, one could make up an aptitude test designed to indicate for which occupation - that of translator or interpreter - one has more aptitude.

\section{REFERENCES}

CONDON, Jr., J.C. (1980) : Cultural Dimensions of Communication, The Simul Press, Inc.

IBUKITYAMA, Taro (1969) : Methods and Problems in Industrial Psychology, Minerva Shobo.

KODAKA, Nobumitsu (1984) : The Job of Translation, President, Inc.

KURACHI, Saichi, Yasuo MATSUYAMA and Tatsuo NAKATSU : Scales of Achievement Motive by Sentence Completion Sentence, Osaka Daigaku Kiyo, 25.

SAMOVAR, L.A., R.E. PORTER and N.C. JAIN (1981) : Understanding Intercultural Communication, Wadswort, Inc.

SATO, Ryoichi (1984) : Translation Situations in the World, Mainich Shinbun.

SUPER, D.E. (1957) : The Psychology of Careers, Harper \& Brothers.

TOYOHARA, Tsuneo (1955) : Industrial Psychology, Kyoritu Shuppan.

TOYOHARA, Tsuneo (1965) : Vocational Aptitude, Kondansha.

UNO, Yoshiyasu (1981) : "Intercultural Refractions Between East and West", Keio Communication Review, $\mathrm{n}^{\circ}$ 2, March, pp. 59-69.

UNO, Yoshiyasu, Satoshi KUBO (1984) : "Knowledge Utilization and Transcultural Refractions", Keio Communication Review, $\mathrm{n}^{\circ}$ 5, March, pp. 3-13.

YANAI, Haruo (1975) : Course Selection and Aptitude, Nikkei Shinsho.

Table 1. Mean of the Achievement Motive Scores

\begin{tabular}{|c|c|c|c|}
\hline Subjects & Translators & Interpreters & Dualists \\
\hline Whole group & $0,834(30)$ & $1,08(28)$ & $0,957(34)$ \\
\hline $\begin{array}{c}\text { Well-adapted } \\
\text { Subjects }\end{array}$ & $0,857(21)$ & $1,010(25)$ & $1,126(19)$ \\
\hline
\end{tabular}

() number of subjects

Table 2. Discriminant Analysis

\begin{tabular}{|c|c|c|c|c|c|c|}
\hline \multirow[b]{2}{*}{ (1) } & \multicolumn{5}{|c|}{ Analysis Groups } & \multirow{2}{*}{\begin{tabular}{|c|}
$\begin{array}{c}\text { Percent } \\
\text { of Correct } \\
\text { Discrimination }\end{array}$ \\
$81 \%$ \\
\end{tabular}} \\
\hline & & AT (21) & VS & WAI ( & & \\
\hline \multirow{2}{*}{ (2) } & \multirow{2}{*}{ WAT (21) } & \multirow{2}{*}{ VS } & \multirow{2}{*}{ WAI (25) } & \multirow{2}{*}{ VS } & \multirow{2}{*}{ WAD (19) } & $\begin{array}{c}\text { CRITERION } \\
1 \% \\
71 \%\end{array}$ \\
\hline & & & & & & $\begin{array}{c}\text { CRITERION } \\
2 \\
66 \%\end{array}$ \\
\hline
\end{tabular}

( ) number of subjects 
Fig. 1 Characteristics of WAT and WAI

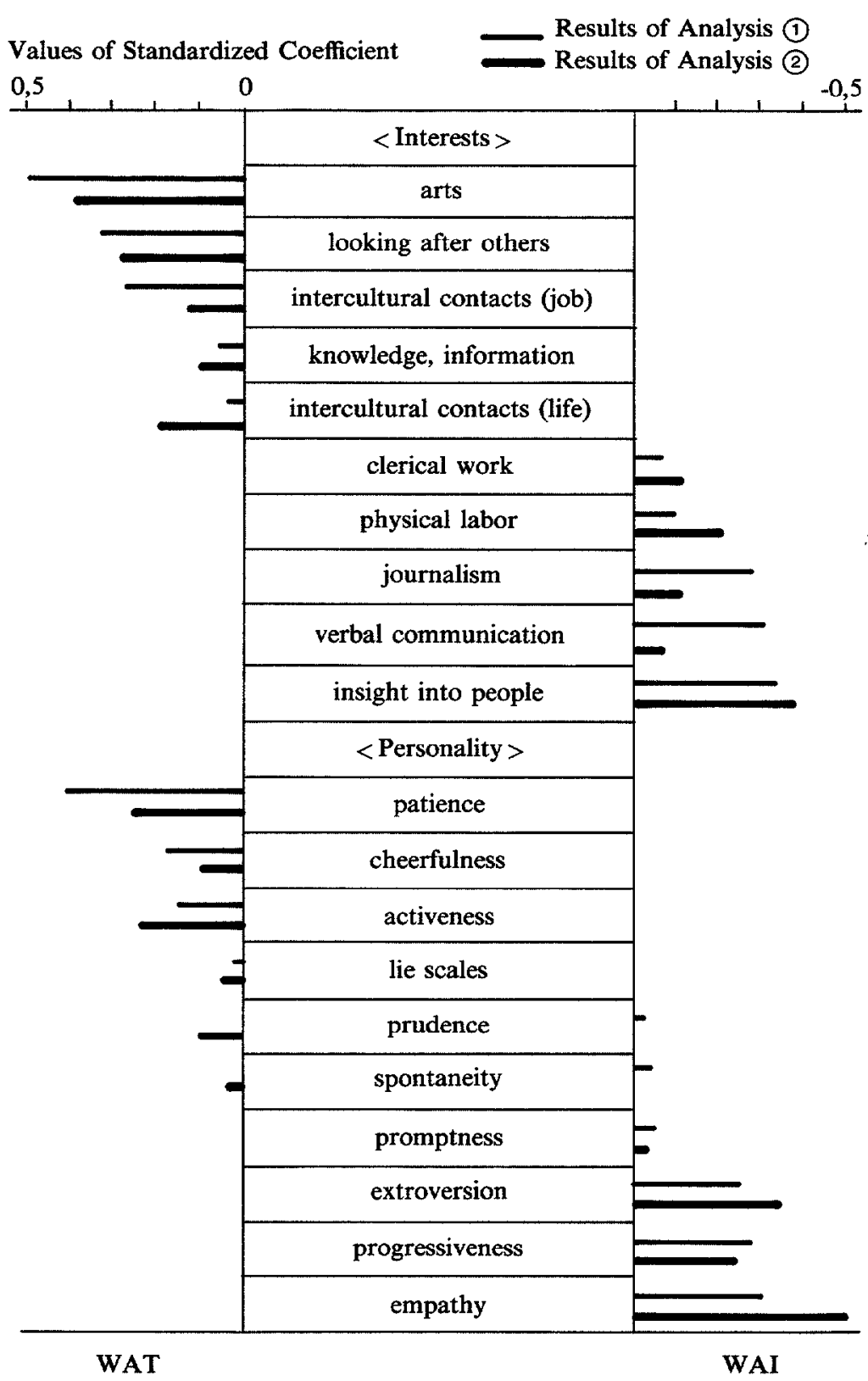


Fig. 2 Cumulative Relative Frequency Distribution of Diseriminant Scores of WAT and WAI

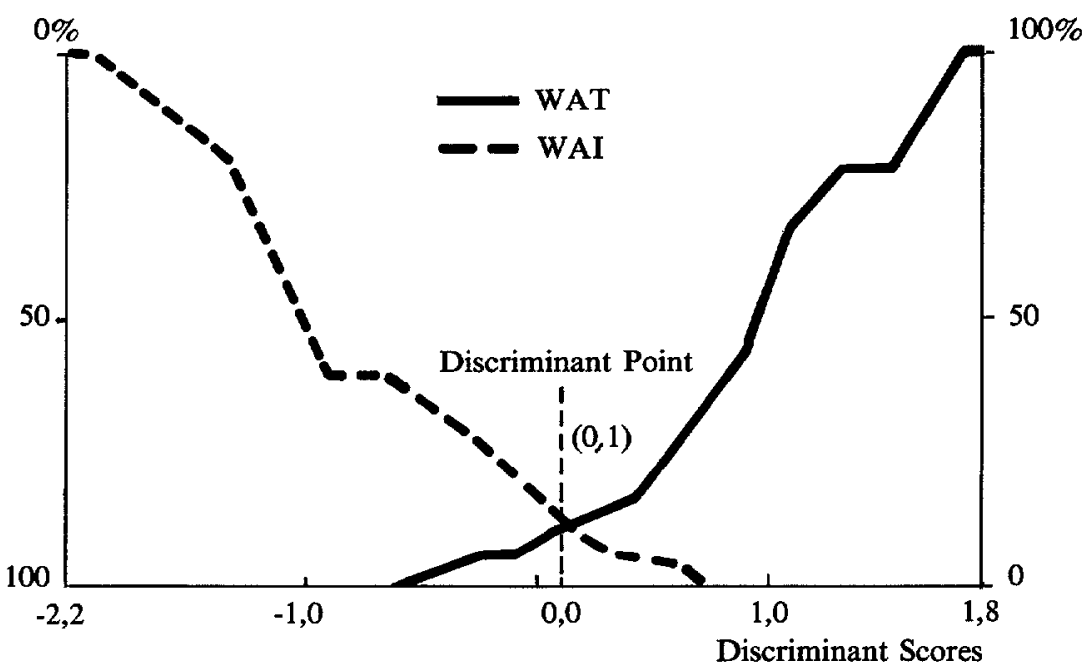

Fig. 3 Plotting Graph of Discriminant Scores of WAT (•), WAI $(X)$ and WAD $(\Delta)$

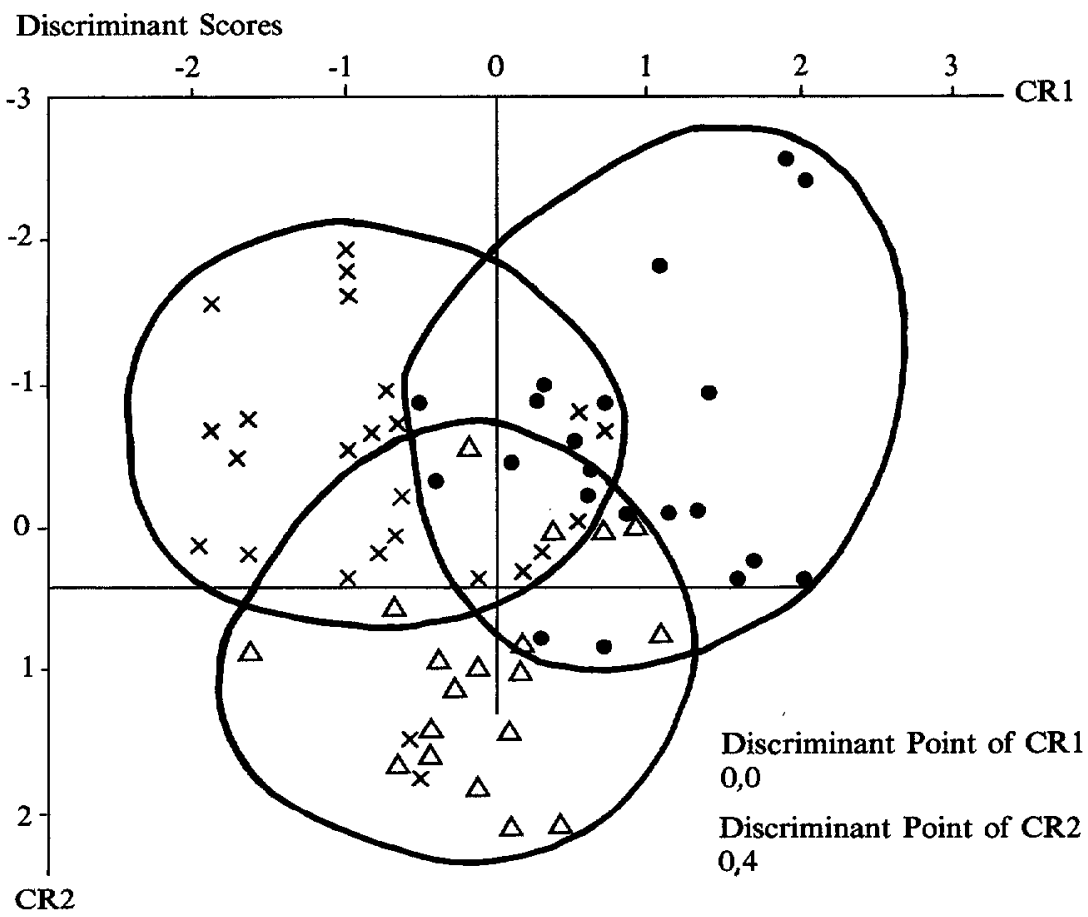

